\title{
THE ROLE AND IMPORTANCE OF INTERMODAL TRANSPORT IN CROATIA FOR EU COUNTRIES
}

\author{
BENDEKOVIC, J.; RogOZAR, Z. \& NALETINA, D.
}

Abstract: Development of information technologies and market globalisation created the need for better and cheaper transport being satisfied by intermodal transport. Today, Republic of Croatia is crossed by X Mediterranean corridor, VB as branch of $X$ corridor, VII Rajna - Danube - Sava and in the future by XI Baltic - Adriatic corridor. Port Rijeka in present and future European transport corridor becomes the port of entry and exit for goods and general cargo between the countries of Middle and Eastern Europe and countries of Middle and Far East. Development of intermodal transport in Croatia has a comparative advantage relative to Slovenia and Italy, since in Croatia there is possibility of using waterway Sava - Danube when transporting containers and general cargo. Intermodal way includes cooperation, but excludes unfair competition of different ways of transport and the largest part of transport uses maritime way, rail, inland water ways, road and air.

Key words: intermodal transport, EU's corridors, railway track, container terminal
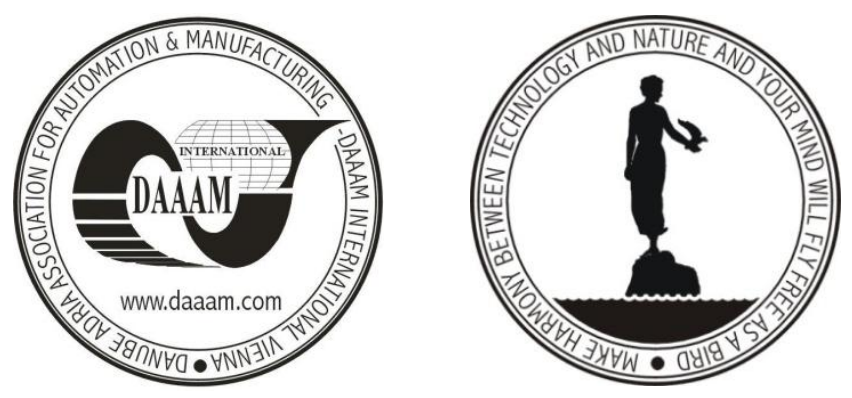

Authors' data: Univ.Prof. Dr. Sc. Bendekovic, J[adranka]*; Rogozar, Z[latko]**; Naletina, D[ora]*, *Faculty of Economics and Business, J. F. Kennedy 6, 10000, Zagreb, Croatia, ** HZ Cargo, Trg kralja Tomislava 11/ I, 10000 Zagreb, Croatia, jadranka.bendekovic@efzg.hr, rogozarz@gmail.com,dora.naletina@efzg.hr

This Publication has to be referred as: Bendekovic, J[adranka]; Rogozar, Z[latko] \& Naletina, D[ora] (2014). The Role and Importance of Intermodal Transport in Croatia for EU Countries, Chapter 22 in DAAAM International Scientific Book 2014, pp.267-278, B. Katalinic (Ed.), Published by DAAAM International, ISBN 978-3901509-98-8, ISSN 1726-9687, Vienna, Austria

DOI: $10.2507 /$ daaam.scibook.2014.22 


\section{Introduction}

The processes of forming the functional and modern transport systems, of the establishing the rules of the market transactions and the introduction of new technologies into the everyday transport of passengers and goods are the requirements necessary for a new transformation of transport system in Croatia, especially after entering the EU and the liberalized international market.

By entering the European Union, we have also entered the sphere of globalized market which calls upon constant and fast changes of business conditions, as well as comprehensive traffic solutions (especially the integrated ones). This type of market and the quick market changes lead to continual emergence of various issues in the work processes and, therefore, ask for quick adjustments of the organizational transport systems of Croatia. In order for the whole transport system to pass through a true transformation and remain sustainable, all of this being in accordance with the preparation of the European transport space for the future, we in Croatia as well have to follow the guidelines of the European Union concerning transportation.

It is a well-known fact that the Republic of Croatia commands an extraordinary geographical and geotraffic position. In that, its strategy of the transport development should uphold the development of all intermodal transport elements, with the final goal of reducing transport costs, providing environmental protection, and enhancing the transport safety. Synchronized transport, principally by means of sea, road, river, railway and air, has largely become the mode of transportation in Croatia as well. Intermodal transport at present comprises $15 \%$ of the total transport of goods, this share being already 25-30 \% in more developed countries in Europe and the rest of the world. Intermodal transport becomes a priority, especially in those areas where there is a possibility of combining different transport modes.

The comparative advantage of the Republic of Croatia lies in the interconnectedness of Pan-European traffic corridors, namely V, VII and X, with the ports of the Adriatic basin and the flows of the rivers Danube and Sava. The advantage is visible in determining the EU key corridors, namely, out of nine key EU corridors, two of them (the Mediterranean Corridor and the Rhine-Danube Corridor) cut through Croatia. The Adriatic is an arm of the Mediterranean Sea, most deeply cut into the European mainland. By shipping the goods in containers across the sea to the northern Adriatic, without doubt, the cheapest mode of transportation is used, thereby maximally shortening the route, as opposed to more expensive transport by land. It is the natural, the shortest and the most economical route to connect Europe with the Mediterranean, and further through the Suez Canal with the majority of Asian, African and Australian countries. The European Union itself has, in its longterm transport strategy, listed the Port of Rijeka as the head intermodal centre and the starting point of one of the transport routes.

The sea route between the Suez Canal and the Port of Rijeka in the northern Adriatic extends to a distance of only $1,254 \mathrm{~km}$, while the routes to the ports of the North Sea match nearly three times the distance. Therefore, the navigation from the 
Suez to the ports of the North or the Baltic Sea is 10 to 14 days longer (one direction only). In the light of the rapid increase in fossil fuel prices, the advantages of the Adriatic route become more and more evident. The Adriatic route connects two large areas of the world, complementary in their economies.

It is presumed that, to the rail transport mode first and foremost (this too being the guideline laid down in the White Paper published by the EU in 2011) and then to all other modes of transport, changes should be made in order to meet the demands of the aforementioned intermodal, integrated and liberalised market. Considering all the facts indicated above, we need to completely rearrange the strategic and operative transport management in order to exploit the aforementioned geographical and geotraffic position and use revenues from the economic rent.

\section{Intermodal transport and the role of European corridors in the Republic of Croatia - today and in the future}

Geo-traffic, geostrategic and ecological sustainability of certain transport modes cannot be achieved without strategically investing in the entire transport infrastructure, especially the railway, port, river, road and air transport infrastructure, as well as in the terminals and transport and logistics centres, which could enable easy development of intermodal transportation (Bendekovic \& Arzek, 2008).

In the Republic of Croatia, there is an adequate road infrastructure, but it would need some modifications (the route to Dubrovnik and the section from Zagreb to Sisak) in order to secure integrated road infrastructure.

In the circumstances where the international trade comprises three quarters of the maritime transport, and when the container ships are being defined in technical and technological terms, it is now high time to develop certain transport modes and facilities, with the aim of successfully developing intermodal transportation on the territory of Croatia.

The benefits of intermodal transportation development lie in the process of connecting all the operators and parties involved in the international trade between Southeast Asia and the EU countries, with the aim of lowering the transportation costs included in the prices of goods, which is of a great interest to European consumers.

On 28th June 2010, the EU signed the Declaration in Szczecin in which it is stated that the Port of Rijeka is the input/output port, i. e. the southern door to the VB corridor in the international transport of goods between Southeast Asia and the countries in South-east Europe (Germany, Austria, Hungary, the Czech Republic, Slovakia, Poland and, in the future, the Baltic countries) (Klaster intermodalnog prijevoza).

As the Port of Rijeka holds great strategic importance for the EU countries, the following investments are fully justifiable: 
Bendekovic, J.; Rogozar, Z. \& Naletina, D.: The Role and Importance of Intermoda...

- In the new Omisalj, Krk island container terminal, a part of the Port of Rijeka gravitational zone;

- In the construction of the electrified double track Rijeka - Zagreb railway line;

- In the reconstruction of the Sava - Danube river route.

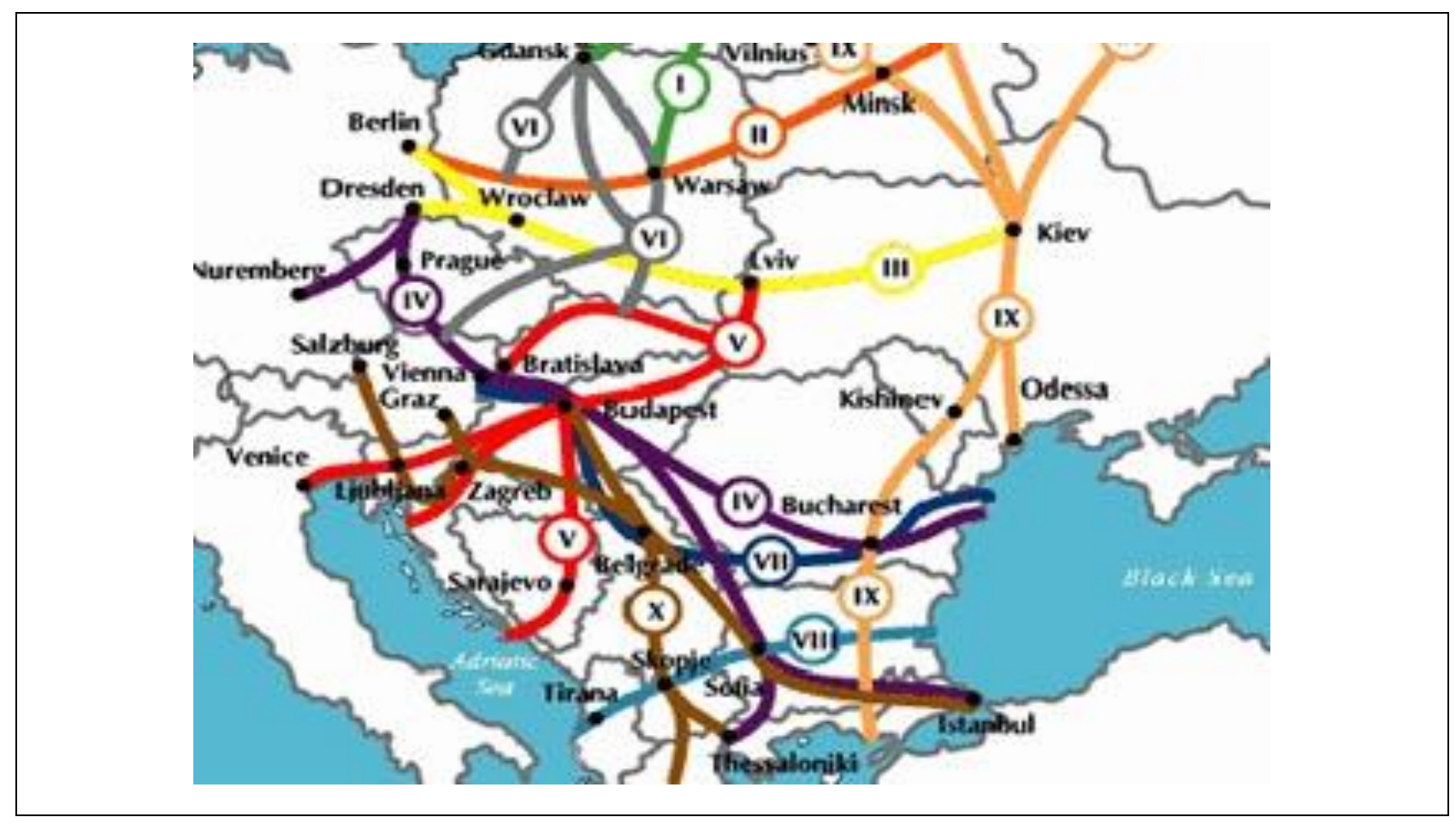

Fig. 1. Pan-European corridors that pass through Republic of Croatia

All of these investments render the possibility of full utilization of intermodal transport in the Republic of Croatia, thereby exploiting the advantages of its favourable geo-traffic position.

It is in the EU's best interest with respect to South-east Europe countries, which feel somewhat isolated from the commerce that passes through North European ports, mainly due to the overbooking, that the goods intended to be placed on those specific markets find more cost-effective and safer path through the Port of Rijeka, by means of intermodal transport.

\section{The role of the Port of Rijeka in intermodal transport}

Geo-traffic position and significance of the Port of Rijeka represent the central trasport and economic point of Croatia and the EU (Bendekovic \& Vuletic, 2013). It is the intersection of marine and mainland routes, Croatian and European corridors connected through the VB Corridor to the X, VII and XI (the Mediterranean, the Rhine - Danube, and the Baltic-Adriatic Corridors) (Milos et al, 2010). The Port of Rijeka is a member of NAPA (North Adriatic Ports Association). All the ports in the North Adriatic region are those most deeply cut into the European mainland, which is not the case with the rest of the Mediterranean ports. The advantages of these geographical locations are in the fact that the shipping companies, by choosing the 
North Adriatic ports as their ports of discharge, choose the most cost-effective routes, since the goods that are shipped by means of sea or rivers have the lowest transportation costs in relation to other means of transport. Medium-term and longterm demand for transhipment in the ports which are members of NAPA is bigger than their present capacity. This calls for the application of a well-known 'ARA' model (Amsterdam Rotterdam Antwerp), which implies that the North Adriatic ports should specialize according to the principles of comparative advantage. Therefore, the decision was made that the Port of Rijeka gets to be the main container port of the North Adriatic.

Taking into consideration that the container shipping on land prefers the railway mode of transportation which, combined with river transport, renders a true profitability, the construction of the Omisalj, island Krk main terminal is put forward. The terminal would be directly connected to the new lowland railway line, which would cross over the newly built bridge into the Omisalj, island Krk business zone, where now Janaf, DINA-Petrokemija and the LNG terminal are situated.

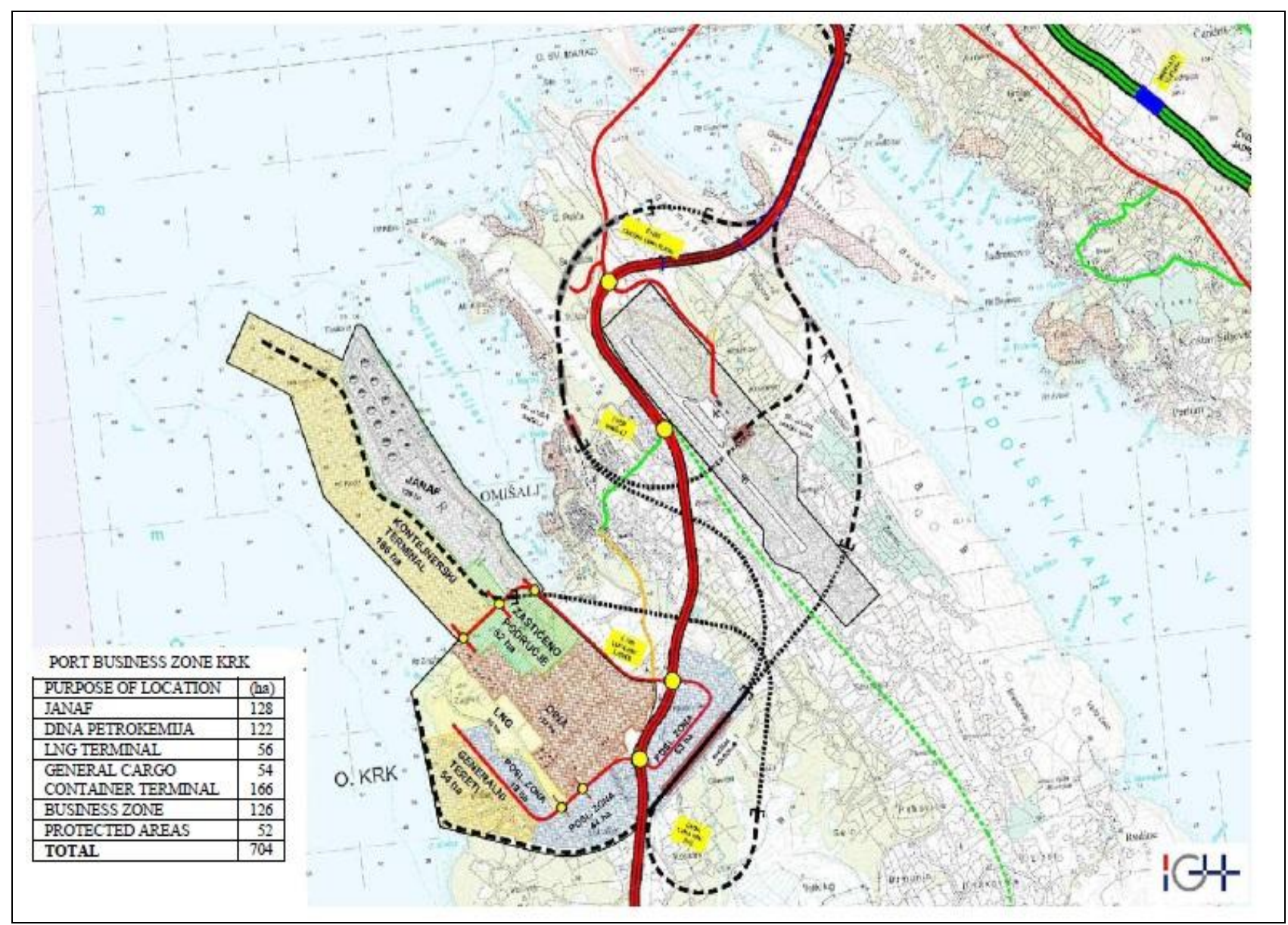

Fig. 2. Future look of container terminal of Port of Rijeka at the island Krk

Comparative advantage of the Port of Rijeka with respect to other NAPA members is:

- Mooring of vessels with a draught up to $20 \mathrm{~m}$, therefore capable of receiving new generation ships in terms of technical and technological achievements (Kos et al, 2010); 
Bendekovic, J.; Rogozar, Z. \& Naletina, D.: The Role and Importance of Intermoda...

- The possibility of using the Sava-Danube-Rhine river route, which is not the feature of other North Adriatic ports.

The Port of Rijeka will, together with the container terminal on the island of Krk directly connected to the new lowland railway line, river routes and the full profile highway, represent a strong multiplying factor in the Croatian economic growth, as well as in the economic growth of others south-eastern EU members.

\begin{tabular}{|l|c|l|l|l|c|c|}
\hline Year & General & Bulk & Wood & Liquid & Container & TOTAL \\
\hline $\mathbf{2 0 2 0}$ & 978.628 & 4.283 .563 & 441.976 & 7.171 .299 & 7.551 .130 & 20.426 .596 \\
\hline $\mathbf{2 0 2 5}$ & 1.134 .498 & 4.729 .399 & 537.732 & 7.537 .108 & 12.048 .280 & 25.987 .017 \\
\hline $\mathbf{2 0 3 0}$ & 1.315 .194 & 5.221 .639 & 654.233 & 7.921 .576 & 18.346 .690 & 33.459 .332 \\
\hline $\mathbf{2 0 3 5}$ & 1.524 .671 & 5.765 .111 & 795.574 & 8.352 .656 & 26.268 .310 & 42.679 .732 \\
\hline $\mathbf{2 0 4 0}$ & 1.767 .511 & 6.365 .149 & 968.424 & 8.750 .348 & 36.336 .680 & 54.188 .112 \\
\hline
\end{tabular}

Tab. 1. Traffic demand forecast for all cargo in the Port of Rijeka (measured in tons)

The reason for the construction of the container terminal on the island of Krk (the Port of Rijeka gravitational zone) lies in the economic justification of container shipping, under the condition that intermodal modes of transport are used (marine, railway and river). Economically speaking, it is the most appropriate mode of transportation, due to the lowest transportation costs. Today, the demand for container shipping shows the highest growth rate in the marine markets. Thus, there are genuine reasons for the further development of intermodal transport, which is of great economic interest to the EU and Croatia.

At this moment, the Port of Rijeka has two terminals: Brajdica terminal, 300.000 TEU and Zagrebačka obala terminal, 700.000 TEU (Port of Rijeka Authority, 2014). Taking into consideration that the Port of Rijeka has completely used all of the space available, the decision was made to build the container terminal on the island of Krk (Omisalj), 4,2 million TEU.

New locations have been chosen in the Omisalj, Krk island area, which would be able to receive the biggest ships (with the draught of up to $20 \mathrm{~m}$ ). The locations are:

- Pusca (Krk island) location Krk 1;

- Tenka punta (Krk island) location Krk 2;

- Blatna (Krk island) location Krk 3.

Location Krk 3 would have the biggest capacity for transhipment. All three locations enter the industrial area of the island of Krk, which encompasses the northeastern part of the island (Omisalj town area). The goal of the EU is to develop a highly intermodal node there, already known to European experts as 'South Rotterdam'. 


\begin{tabular}{|l|c|c|c|c|}
\hline \multicolumn{1}{|c|}{ Terminal } & Year & Demand & Total capacity & $\begin{array}{c}\text { Utilization of } \\
\text { capacity }\end{array}$ \\
\hline Brajdica 1 & 2010 & 219.739 & 160.000 & $137 \%$ \\
& 2011 & 252.000 & 160.000 & $158 \%$ \\
& 2012 & 289.100 & 160.000 & $181 \%$ \\
\hline Brajdica 2 & 2013 & 331.600 & 300.000 & $111 \%$ \\
& 2014 & 380.300 & 300.000 & $127 \%$ \\
\hline Zagrebacka obala & 2015 & 436.480 & 590.000 & $74 \%$ \\
\hline Krk 1 & 2016 & 487.000 & 2.190 .000 & $22 \%$ \\
& 2020 & 755.113 & 2.190 .000 & $34 \%$ \\
& 2025 & 1.204 .828 & 2.190 .000 & $55 \%$ \\
& 2029 & 1.686 .400 & 2.190 .000 & $77 \%$ \\
\hline Krk 2 & 2030 & 1.834 .669 & 2.890 .000 & $63 \%$ \\
& 2031 & 1.971 .200 & 2.890 .000 & $68 \%$ \\
& 2032 & 2.118 .000 & 2.890 .000 & $73 \%$ \\
& 2033 & 2.275 .400 & 2.890 .000 & $79 \%$ \\
\hline Krk 3 & 2034 & 2.444 .700 & 3.000 .000 & $68 \%$ \\
& 2035 & 2.626 .831 & 3.000 .000 & $73 \%$ \\
& 2040 & 3.633 .668 & 3.000 .000 & $101 \%$ \\
\hline
\end{tabular}

Tab. 2. The ratio between traffic demand and terminal's capacity (TEU)

Now and in the future, the most important features of the Port of Rijeka, which will be of a global importance to all the parties who will use the Port of Rijeka services, are to provide: standard transhipment technology, standard information technology, good capacity of transhipment terminals, safe berths to the mooring vessels, reasonable port charges and transhipment costs, and appropriate connections with the hinterland. All of these components will give rise to the Port of Rijeka and make it more competitive and attractive to those involved in the activities of transportation.

\section{Zagreb - Rijeka - Botovo High-Efficiency Railway Line}

Based on the construction project of the new Zagreb - Rijeka lowland double line electrified railway, it stretches from Zagreb to Karlovac, passes near Duga Resa and Ogulin to Josipdol, Dreznica and runs through the Velika Kapela to reach Novi Vinodolski. One branch line would lead to Bakar and Rijeka, and the other one across the newly built bridge for the road and railway transport, directly to the aforementioned business zone of the Omisalj (Krk island) container terminal. The new Botovo - Zagreb - Rijeka railway (Hungary - Croatia border) would be 328,7 km in length, while the length of the Zagreb - Rijeka line would be shortened by $57 \mathrm{~km}$. The construction of this railway will boost the freight transport five times in capacity, cargo trains will run at the approximate speed of $120 \mathrm{~km} / \mathrm{h}$, while passenger trains at 160 to $200 \mathrm{~km} / \mathrm{h}$. The cargo traffic will comprise $80 \%$, and the passenger traffic $20 \%$ of the total transport. 
Railway transportation, in combination with inland river transport, is the most appropriate mode of transport of goods, since it completely meets the requirements of the '3E' Model (ecological sustainability, energy rationalization and economic benefits). For this reason, the EU dictates that this combination of transport modes and means (railway and river mode) should comprise 85\%, while the road transport only $15 \%$ of the total transportation.

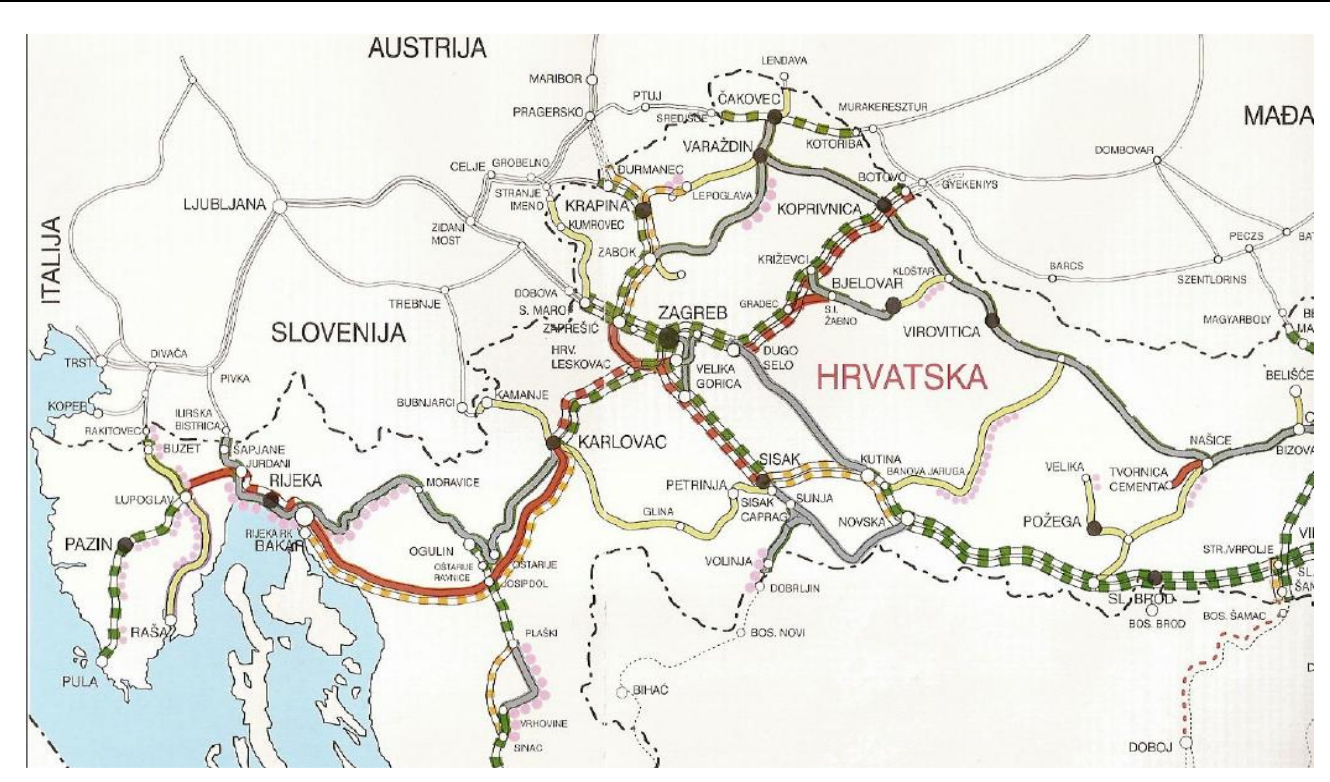

Fig 3. Proposal for development of railway network of Croatian Railways till 2020 (with reference to the corridor VB)

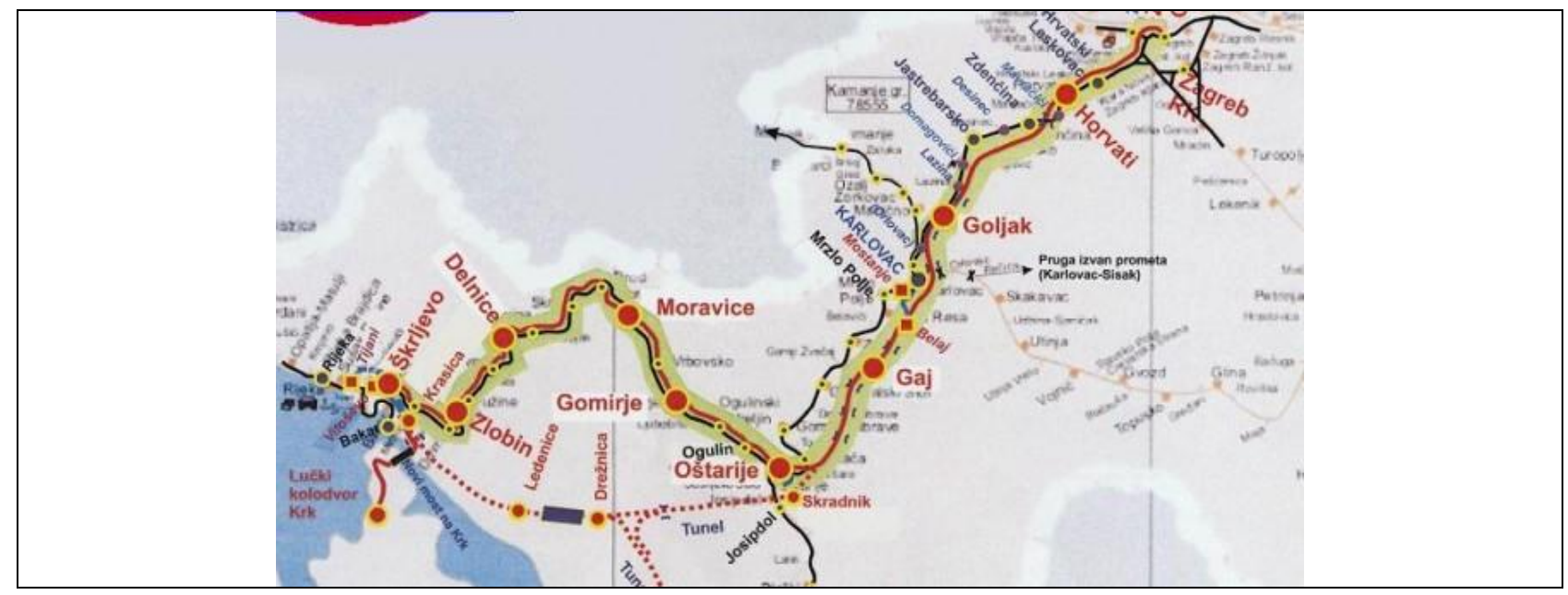

Fig. 4. Lowland railway Zagreb-Rijeka

The comparative advantage of railways, in combination with river modes renders:

- Lower transport costs;

- Higher transport capacities;

- Reduction of energy sources use;

- Environmental protection; 
- Elimination of traffic jams, i. e. traffic bottlenecks in the transportation of goods (Zelenika \& Nikolic, 2003).

\section{The effects of the Danube Region - Adriatic Corridor on the intermodal transport development}

The establishment of a new river-rail connection between the Danube Region and the Adriatic, i. e. between the Port of Rijeka and Vukovar, implies the construction of the Danube - Sava Multipurpose Canal, the reconfiguration of the river Sava routes from Slavonski Brod to Vukovar and Slavonski Samac - Sisak in order to achieve navigability class IV, and the construction of the new Rijeka Zagreb high-efficiency railway. The Croatian inland water routes belong to the VII Danube Corridor (Dundovic \& Vilke, 2009).

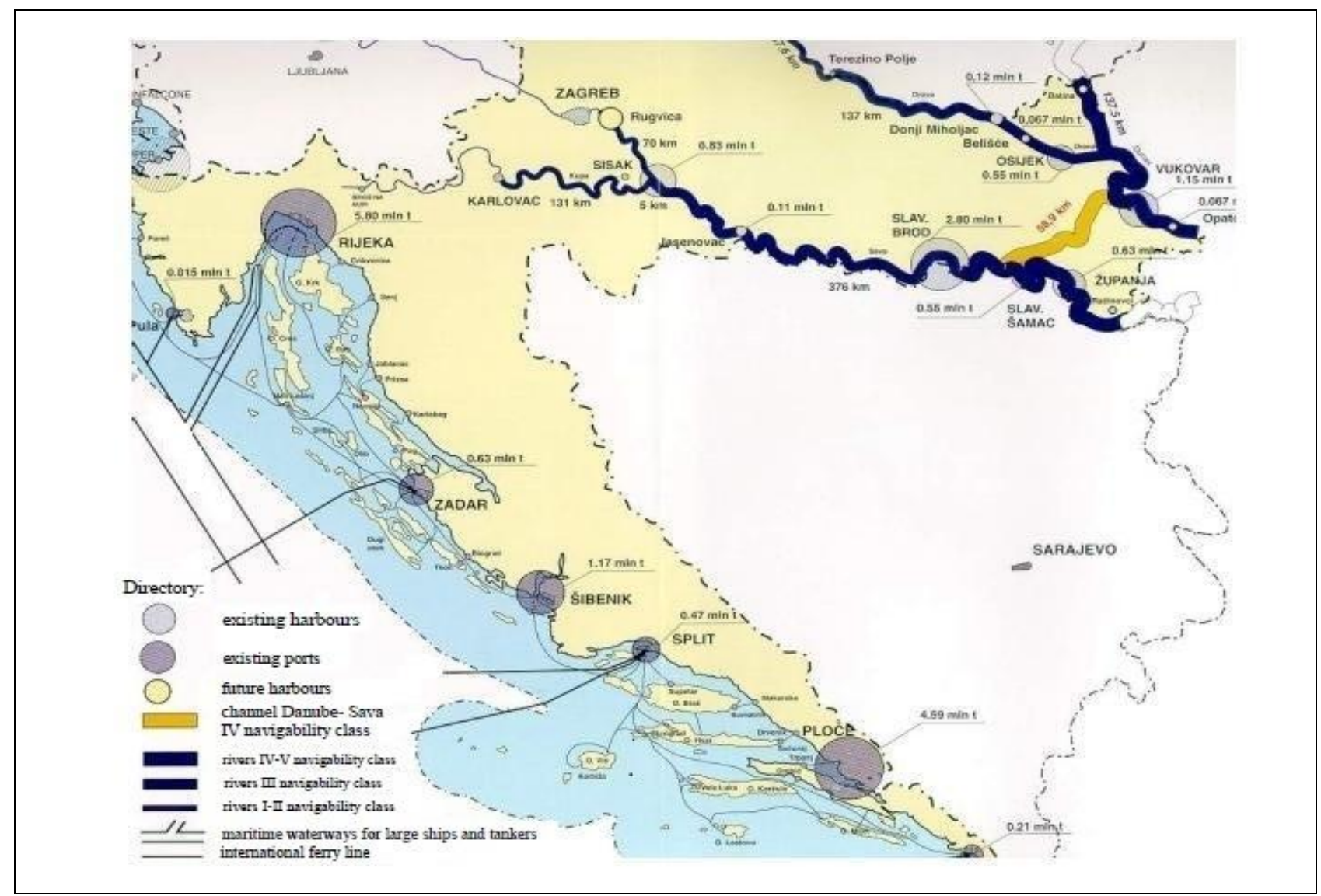

Fig 5. Croatian inland waterways

The transportation by means of the Danube - Sava Multipurpose Canal is a matter of extreme importance, considering the fact that it will connect the VII (Danube) and the X (Pan-European) Corridor, as well as the VB section of the PanEuropean Traffic Corridor (Nikolic, 2003). With the construction of Croatian inland water routes network and its connection to Danube and further to the Rhine - Main Danube Canal on one hand, and with the connection of the same routes to the Rijeka Zagreb Lowland Railway on the other, the requirements for the successful use of intermodal transport are met. 
The use of intermodal transport in these corridors has an extremely important economic aspect, as the valuable communication with the Middle Europe economic and traffic centres is established in this way (Republic of Croatia Ministry of sea, transport and infrastructure, 2008). With the exploitation of the Danube - Sava Canal, the conditions will be created for the certain transport routes to be transferred onto the rivers, which would be favourable to all the parties involved in the international trade with regard to costs, and it would have positive effects on the general economic development of Croatia (Hlaca et al, 2010).

The Danube Region - Adriatic Traffic Corridor as an intermodal river-railway route which connects the Port of Rijeka to the Port of Vukovar would be 566,9 km in length as shown:

- The Danube - Sava Canal from Vukovar to Samac, 61,4 km in length;

- The Sava Waterway, navigability class IV, 345,5 km in length (Sisak - Samac);

- The Zagreb - Rijeka Railway, $160 \mathrm{~km}$ in length (***, 2008).

For the valorisation of the Danube Region - Adriatic intermodal transport route it is necessary to build another railway track between Zagreb and Sisak, and to thoroughly reconstruct the Rijeka and the Zagreb junction. The project of the lowland railway construction should be viewed together with the project of the Multipurpose Danube - Sava Canal along the Danube Region - Adriatic Corridor. In this way, the multimodal transport route will be created, 566,9 $\mathrm{km}$ in length, connecting the Danube Corridor VII, the Pan-European Corridor X and the VB section of the PanEuropean Traffic Corridor. To that end, the EU is interested in the execution of these projects and willing to finance them by means of concessions from the Structural and Cohesion Funds.

\section{Conclusion}

The role and importance of intermodal transport are defined as a part of the transport policy of Croatia and the broader region on the EU territory. It is essential to establish the priorities of the investment dynamics and the system for financing the construction of the transport terminal on the island of Krk and the accompanying infrastructure. Most of the investments will be made into the reconstruction of the existing and the construction of the new transport infrastructure facilities in the territory of the Republic of Croatia.

The capital intensive processes of the new development potential investments into the Omisalj, Krk island container terminal, the lowland Rijeka - Zagreb full profile railway, the second track of the Zagreb - Sisak railway, and the construction of the Sava - Danube waterway will, according to some research, be profitable for the potential private partners.

It is economically justified to use different IPP models (concession and PIF), those being modalities most appropriate for the Croatian economy, as well as the best choice for the country, i.e. for the public administration in order to develop certain 
economic branches with the minimum burden to the state budget. Croatia is interested in signing the contract based on the IPP because of the financial implications naturally, but also because of the construction and operational management of the transport infrastructure conducted by a private partner.

The construction and the operative use of the main modern intermodal infrastructure facilities along the international VB, X and VII Corridors are the key factors in the strategic development of transport and economy in Central Europe countries and in the Republic of Croatia. These factors also form a strategic link between the EU and the countries of Near East, Middle East and Far East Asia, which is the largest trading area of the world today and in the future, in the light of the fact that it comprises two-thirds of the global producers/consumers entities.

Intermodality entails cooperation and excludes severe competition among different modes of transport. Croatia offers many possibilities for the development of intermodal transportation which, for that reason, should become the transport services brand oriented towards the EU, rest of Europe and the world, as well as a generator of development of the EU and Croatia economies, which implies the creation of new values. Finally, the most important is that EU is interested in the execution of these projects and willing to finance them by means of concessions from the Structural and Cohesion Funds.

\section{References}

Bendekovic, J. \& Arzek, Z. (2008). Transport $i$ osiguranje (Transport and Insurance), Mikrorad d.o.o., ISBN 953-6286-85-0, Zagreb

Bendekovic, J. \& Vuletic, D. (2013). Development opportunities of Port of Rijeka in the future; Book of Proceedings 2nd International Scientific Conference Economic and Social Development, Filipovic D. \& Goltnik (Ed.), pp. 74-82, ISBN 978-9616825-73-3; Paris, France, April 2013, Varazdin development and Entrepreneurship Agency, Varazdin, Croatia \& Faculty of Commercial and Business Sciences, Celje, Slovenia

Dundovic, C.; Kolanovic, I. \& Grubisic, N. (2011). Integralni pristup planiranju rijeckoga luckog sustava (Integral Approach to Rijeka Port System Planning), Suvremeni promet, Vol. 31, No. 5-6, (September 2011) 502-509, ISSN 0351-1898

Dundovic, C. \& Vilke, S. (2009). Izgradnja visenamjenskog kanala Dunav-Sava u funkciji prometne integracije Podunavlja i Jadrana (The construction of the DanubeSava multipurpose canal aiming the transport integration of the Danube Basin and the Adriatic Sea). Pomorstvo, Vol. 23, No. 2, (December 2009), 589-608, ISSN 1332071

Hlaca, B.; Rudic, D. \& Himig, S. (2010). Rail Transport - An Important Factor in The Port of Rijeka Development, Promet-Traffic \& Transportation, Vol. 22, No. 5, 379388, ISSN 1848-4069 
Bendekovic, J.; Rogozar, Z. \& Naletina, D.: The Role and Importance of Intermoda...

Port of Rijeka Authority (2014). Environmental Impact Assessment for Reconstruction of railway stations Rijeka and Rijeka Brajdica related to construction of new (Zagreb Pier) and extension of existing (Brajdica) Container Terminal Institut IGH d.d. (2011). Prostorna i prometna integralna studija Primorsko-goranske zupanije i Grada Rijeke (Spatial and transport integral study of Primorje-Gorski Kotar County and the City of Rijeka), Available from: http://www.zavod.pgz.hr/docs/zzpuHR/documents/291/1.0/Original.pdf, Accessed on:2014-08-12

Klaster intermodalnog prijevoza. Intermodalni prometni sustav u Republici Hrvatskoj (Intermodal transport system in Croatia), Available from: http://shortsea.hr/sites/kip.prospektsolutions.com/files/upload/brosura_KIP_hr_za_web.pdf, Accessed on:2014-08-19 Kos, S.; Brcic, D. \& Karmelic, J. (2010). Structural analysis of Croatian container seaports, Scientific Journal of Maritime Research, Vol. 24, No. 2, (December 2010) 189-209, ISSN 1332-0718

Milos, A.; Jakopic, M. \& Milos, I. (2010). New Trans-European Corridor XI BalticAdriatic, Suvremeni promet, Vol. 30, No. 1-2, (December 2010) 18-24, ISSN 03511898

Nikolic, G. (2003). Multimodalni transport - cimbenik djelotvornog ukljucivanja Hrvatske u europski prometni sustav (Multimodal Transportation - Element for Efficient Including Republic of Croatia into European System), Zbornik radova Ekonomskog fakulteta u Rijeci, Vol. 21, No. 2, (December 2003) 93-112, ISSN 13318004

Republic of Croatia Ministry of sea, transport and infrastructure (2008). Development strategy for inland waterway transport in the Republic of Croatia (2008-2018)

Zelenika, R. \& Nikolic, G. (2003). Multimodalna ekologija - cimbenik djelotvornoga ukljucivanja Hrvatske u europski prometni sustav (Multimodal ecology - the factor of the efficient integration of the Republic of Croatia in the European traffic system), Nase more, Vol. 50, No. 3-4, (October 2003) 93-112, ISSN 0469-625

*** (2008) Nacionalni program zeljeznicke infrastrukture za razdoblje od 2008. do 2012. godine (National Railway Infrastructure Program for the period from 2008 2012) Available from: http://www.propisi.hr/print.php?id=7830, Accessed on:201408-02

*** (1999) Strategija prometnog razvitka RH (Strategy of Transport Development for Croatia). Available from: http://narodne-novine.nn.hr/clanci/sluzbeni/271868.html, Accessed on:2014-08-12 